\title{
A Mismatch between the Policies in Preservice Teachers Training and Their Jobs in the Colombian Education System
}

\author{
Angélica Aguillón-Lombana, José Marín-Juanías \\ Universidad Antonio Nariño, Bogotá, Colombia \\ Email: aaguillon@uan.edu.co,jomarin40@uan.edu.co
}

How to cite this paper: Aguillón-Lombana, A., \& Marín-Juanías, J. (2020). A Mismatch between the Policies in Preservice Teachers Training and Their Jobs in the Colombian Education System. Open Journal of Social Sciences, 8, 429-439.

https://doi.org/10.4236/jss.2020.88035

Received: July 17, 2020

Accepted: August 25, 2020

Published: August 28, 2020

Copyright $\odot 2020$ by author(s) and Scientific Research Publishing Inc. This work is licensed under the Creative Commons Attribution International License (CC BY 4.0).

http://creativecommons.org/licenses/by/4.0/

\begin{abstract}
The objectives of this descriptive study were, first, to identify the main transversal training areas demanded by the public policies in higher education to frame teacher training in undergraduate programs in Colombia and, second, to determine whether the job contexts in which in-service teachers of Básica Primaria and Básica Secundaria ${ }^{1}$ favor or hamper the application of the main transversal competences demanded by the public policies in higher education. Data were collected from the database of the project "Pandemnesis: Archivos Testimoniales, Diarios de la Experiencia, Crónicas y Fuentes desde América Latina" carried out by CLACSO ${ }^{2}$ and La Universidad Distrital Francisco José de Caldas, and a documentary review on teacher training policies. The results suggest that there is a mismatch between the higher education policies issued in Colombia and what the graduates of higher education in pedagogy can do with the competences developed in science and technology and pedagogical research training.
\end{abstract}

\section{Keywords}

Colombian Public Policies for Teachers Training, Science and Technology, Pedagogical Research Training, Educational System Transformation

\section{Introduction}

The structure of the Colombian educational system is based on laws and regulations issued by the Ministry of Education (MEN) and the Colombian government in a wide range of documents, including the Political Constitution of 1991,

${ }^{1}$ These are the most basic levels of the educational process in Colombian education system. ${ }^{2}$ Consejo Latinoamericano de Ciencias Sociales. 
the General Law of Education of 1994 and different decrees released in the last few years. These documents have diverse functions; one of them is to guide and regulate the faculties of education in aspects linked to teachers training. The last of these decrees is 1330, which establishes that any program that aims at this purpose must have a qualified registry that certifies conditions to guarantee teaching practices consistent with contemporary worldwide situations and demands imposed by globalization.

Furthermore, the abovementioned texts include aspects of public policies that regulate teachers' training, theoretical and methodological issues and epistemological implications that must be taken into consideration when teachers are trained in an education faculty. One of those aspects is related to equip teachers with competences to both undertake investigations on pedagogy and disseminate and release information about the findings of their research, through science and technological resources.

However, one of the questions that arise, in relation to teachers' developed competences in their professional training stage, is whether those who end up working in Educación Básica Primaria y Básica Secundaria really have conditions in their workplace to research and publish what they investigate. This is precisely one of the interests of the current study, especially in contexts where poverty and exclusion prevail. Consequently, this article presents the results of a qualitative study, whose specific objectives are:

- To identify the main transversal training areas demanded by the public policies that frame teacher training in undergraduate programs in Colombia.

- To determine whether the job contexts in which in-service teachers of Básica Primaria and Básica Secundaria in different regions of the country favor or hamper the application of the main transversal competences demanded by the public policies in Education.

Consequently, two research questions are posed to guide the attainment of the previous objectives:

- What are the main transversal areas demanded by the public policies that frame teacher training in undergraduate programs in Colombia?

- Do the job contexts in which in-service teachers of Básica Primaria and Básica Secundaria in different regions of the country favor or hamper the application of the main transversal competences demanded by the public policies in Education?

\section{Literature Review}

\subsection{Educational System Transformation}

This theoretical construct is associated with the idea that a society does not become developed if the educational system is not transformed and it must be thought of from a pertinent articulation of the elements and processes that participate in the educational action, as Bustamante (2016) proposes. In this sense, Serna-Dimas (2004) asserts that in the pedagogical field the totality of the social 
world of a group can be addressed in a reflexive way, but also in a transformative one. Then, through it society cannot only be understood, but also transformed. Therefore, the establishment of solid structural foundations for the educational system implies reviewing the social circumstances and the material conditions in which the different communities that inhabit the national territory are immersed. In this regard, Montoya (2017) argues that one of the main difficulties of the educational systems of developing countries is the establishment of educational models of developed countries. This is done because of the desire for competitiveness demanded by the neoliberal policies assumed by the phenomenon of globalization, but without the enough economic investment that guarantees an adequate environment for the generation of knowledge. Therefore, these developing countries must work on public policies to avoid disarticulation among the dynamics of the different orders of society, which implies both that school life be consistent with the school administration and that what is learned there be applicable in people's life reality. Otherwise, it is difficult to achieve a true social transformation.

\subsection{Education Policy}

It is considered as the element that defines all the scaffolding on which an education system works. Thus, a public policy in education is understood as the normative framework that governs the educational task in a state. This framework is structured on founding ideologies in various fields of human development, mainly in political and economic areas. These normative frameworks seek to impact the way of people's thinking, who are no longer conceived as individuals but as subjects who must respond to a particular development model from the hegemonic powers. In this regard, Ghioldi (2006) points out that:

Educational policy is the State's theory and practice in the field of public education. On the one hand, it determines the performance of the State in order for the new generations to prepare for the use of the humanity's cultural assets and to promote the development of people's individual and collective personality according to laws, institutions, aspirations or historical ideals of the nation and, on the other hand, it creates and regulates the organization of school establishments for the realization of such ends (p. 12).

According to Dimate (2017), in this dialogical structure between theory and practice that is promulgated in the construction of a public policy in education, teachers' experience must be present, who are ultimately the bearer of information about their educational context. In addition, they are the experts in a coherent public policy in which dialogues are established between the different social sectors in order to guarantee fairness and quality in accordance with the circumstances of the various social contexts. Thus, according to Montoya (2017), achieving a public policy in education with such characteristics implies not only financial investment and a high degree of dialogue among the different entities of the State, but also among those with the different levels of the civil society. This 
interaction guarantees an adequate connection between the established ideal and the reality that each teacher must face in his/her teaching practices.

\section{Method}

\subsection{Research Design}

This study adopts a qualitative approach framed within the parameters of a descriptive analysis in order to identify the recurrent transversal areas in public policies for teacher training and how they are reflected in the work carried out by these teachers in various teaching contexts. In this regard, Rojas (2015) asserts that the main objective of descriptive studies is to determine people's characteristics, social groups, or phenomena, evaluating various aspects, dimensions, or components of the individual, group, or phenomenon. This process transcends the collection and organization of data and makes connections with elements of the same nature or with people's points of view or attitudes. The qualitative research approach is typical of the social and human sciences. In this regard, Naupas et al. (2013) assert that one of the advantages offered by this approach is the possibility of investigating elements that transcend the plane of objectivity and are inserted into the complexities of human life. In the same way, they argue that thanks to instruments such as in-depth interviews and the bibliographic review, a more complete analysis of the object of study can be carried out while the circumstances and characteristics of different components of social life are specified.

\subsection{Participants, Instruments and Data Collection}

In regards to the participants, 42 teachers enrolled in Básica Primaria and Básica Secundaria education levels within the research project "Pandemnesis: Archivos Testimoniales, Diarios de la Experiencia, Crónicas y Fuentes desde América Latina" carried out by CLACSO and La Universidad Distrital Francisco José de Caldas. They voluntarily decided to be interviewed: 27 women and 15 men. Their ages range from 25 to 47 years; 19 of them studied in public universities and 23 in private institutions. In regards to their job, 11 of them worked as language teachers (English and Spanish) in different courses at the level of Básica Secundaria in the cities of Bogotá, Neiva, Ibagué and Popayán; 5 were Básica Secundaria Social Sciences teachers who worked in public schools in Bogotá; 3 were Básica Secundaria mathematics teachers, two of them worked in public schools in Bogotá and the other in a private school in Villavicencio; 7 were Básica Secundaria Biology teachers in private schools in Bogotá, Tunja and La Mesa; 12 were teachers of Escuela Unitaria ${ }^{3}$ in various rural areas of Cundinamarca, Tolima and Caldas. The other 4 were Básica Primaria teachers who worked in Bogotá.

Regarding the documents reviewed to identify the main transversal areas demanded by the public policies, that frame teacher training in undergraduate programs in Colombia, a source offered by the Ministry of Education called "Normograma" was revised. In this database, the different resolutions, decrees

${ }^{3}$ This is a model in rural education in which one teacher has different courses in the same classroom. 
and laws that are established for the educational sector appear. From that source, ten laws, 15 decrees and a resolution were extracted on the elements that must be taken into account by the programs in charge of teacher training to guarantee their quality.

In relation to the data collection procedures, bibliographic sheets were used to attain the data concerning the first objective of the study. Regarding the second objective, the participants were remotely interviewed via hangout meet. The interview was structured based on three core questions. These central questions were: What were the most recurrent difficulties that you had to face in your academic daily work before the pandemic? What are the most recurrent difficulties in carrying out academic work in these times of pandemic? And what do you think your professional activities will be like after the pandemic?

As previously mentioned above, a database created within the project Pandemnesis: Archivos Testimoniales, Diarios de la Experiencia, Crónicas y Fuentes desde América Latina (2020) was used in this study. This database corresponds to a project of CLACSO and Universidad Distrital Francisco José de Caldas, and researchers from various universities in different countries were involved in. The archive was created by collecting and systematizing personal testimonies on how the pandemic is lived by people in their daily routines. With the aim of determining changes and personal visions people were asked about their past and present experiences and future predictions. With this database it is expected to offer qualitative information for the diagnoses required to the institutions in charge of building policies on different issues and areas, including health, education and economy.

\section{Data Analysis}

In relation to the identification of the main transversal areas demanded by the public policies that frame teacher training in undergraduate programs in Colombia, classification, preliminary understanding, content analysis, coding and categorization of data from Normograma database were the key procedures at this stage to analyze the data. This allowed the identification of two main transversal areas: training in science and technology and pedagogical research training. This analysis is coherent with Hernández-Sampieri and Mendoza (2018) recommendations for this type of studies: starting with the organization and classification of the collected data.

In regards to the teachers' interviews, only 42 of the more than 200 that were collected in the entire testimonial archive about education were selected. This taking into account that in the education area various topics and levels were addressed, but researchers were interested mainly in those that had to do with Básica Primaria and Básica Secundaria levels and with the two recurrent training areas addressed in the policy: training in science and technology and pedagogical research training.

\section{Results and Discussion}

The results regarding the first objective of the study, the identification of the re- 
current transversal training areas demanded by the public policies that frame teacher training in undergraduate programs in Colombia, evidenced that there are two recurrent training areas: training in science and technology and pedagogical research training. The documents reviewed to identify these areas were SCFELP 2013; Ley 1188; Decreto 0272; Decreto 2450; Decreto 1075; Resolución 02041; Decreto 1280; Decreto 4716; Decreto 892; Decreto 1330, among others. In this regard, SCFELP (2013) states that "The permanent requirements of society, the changes that take place in the field of science and technology, as in the human sciences, cannot be excluded of the education training in Colombia" (p. 48).

Furthermore, according to the Ley General de Educación (1994) in Colombia "in the country academic settings are promoted for reflection, construction and dissemination of pedagogical, disciplinary, scientific, social and cultural knowledge. All these aspects are necessary for the qualification of educators in relation to the inclusive, contextualized, differential and intercultural education required for the diverse realities and populations of the country" (p. 56).

All those thoughts are in accordance with the arising of critical pedagogy in which teachers are considered as transformative intellectuals (see Giroux, 1990). That consideration of educators as transformative intellectuals entails going beyond the mere fact of teaching specific information. Consequently, teachers need to address deep teaching processes that allow students to grasp implicit meanings and senses into a discursive structure. To this respect Kumaravadivelu (2012) poses that these educators have to be able to link theory and practice, taking into account different social issues in both, specific and general context. It makes students be more aware of ideologies involved in human actions and acquire information in a meaningful way. Hence, teachers must be inquired oriented, grounded on a commitment to social change, dedicated to the cultivation of situated participations, extended by a concern with critical self- and social-reflection, shaped by a commitment to democratic self-directed education, promised to the continuous action and steeped in a sensitivity of pluralism.

Moreover, according to other documents of public policy in education, teachers must be professionally trained to properly address and meet particular needs of the communities where they work. This implies the recognition of situations that may affect the learning processes of their students and the promotion of situated pedagogical practices aimed at improving the exercise of citizenship, their social condition and their productivity when they are introduced within an economic scope. According to Giroux (1990), teachers are responsible for developing theoretical knowledge and practical skills by understanding students' specific needs. Then, teachers must be able to collect, systematize, analyze and socialize information related to the specificities of their teaching contexts, all of that with the aim of improving their practices. For example, in the SCFELP ${ }^{4}$ (2013) it is stated that "The way the educator is trained and what this means for their relationship with the student once the educator acts in the field, makes a real difference in the operation of an inclusive and quality educational system" (p. 27).

${ }^{4}$ Sistema Colombiano de Formación de Educadores y Lineamientos de Política. 
The reviewed documents also showed that teachers and students have plenty of necessary resources to carry out different processes related to research at different fields, including laboratory practices. In addition, in these documents is asserted that teachers and students from the most remote areas of the country are provided with access to sufficient and qualified information by giving them technological resources and connectivity. According to SCFELP (2013) "The increasing possibilities of fast and complex access to various sources of information and knowledge, through the media and communication platforms, have meaningfully changed educational practices in our country" (p. 18). Overall, the reviewed documents issued by the MEN suggest that teachers and students in Colombia count on the required resources and conditions to succeed in their teaching and learning processes, which, with some skepticism, is widely questioned by theorists and researchers in this field.

The second motivation of this study was to determine whether the job contexts in which in-service teachers of Básica Primaria and Básica Secundaria in different regions of the country favor or hamper the application of the main transversal competences demanded by the public policies in higher education. In relation to this objective, the interviews performed to 42 in-service teachers, concerning the first question, what were the most recurrent difficulties that you had to face in your professional activities before the pandemic? revealed that there are some areas in the country, even in big cities such as Bogotá, in which students do not even have electricity or sanitary services (see Figure 1). That is why some of them do not have electronic devices such as cell phones or computers. Therefore, teachers must provide the students with photocopies or other kind of physical elements they can work, which happened after the pandemic and still happens.

In relation to the second question, what are the most recurrent difficulties in carrying out academic work in these times of pandemic? the collected data revealed that the lack of technological and financial resources to provide remote classes drastically hampered the attainment of the different course learning objectives. For example, some teachers exposed cases of students in which they do not have data plans to reply messages via WhatsApp - which is the most basic tool to communicate during the pandemic class sessions-and they must solve the problem by investing their own money to buy plans for them because, otherwise, students are left behind. The teachers from rural zones said that it is very common that students have to climb big trees in order to get any signal because the connection service is very fragile. These teachers also said that there are cases in which their students go to borrow a cell phone from a neighbor to be able to contact the teacher and find out what activities they must do.

Another finding through this question was the recurrent teachers' complaint related to the need of increasing capacity of the internet plans they have, as well as the lack of financial support to pay the bills of those plans, which ends up being assumed by the teachers (see Figure 2). This situation hampers the only possibility to perform the classes in this pandemic: remote work. 


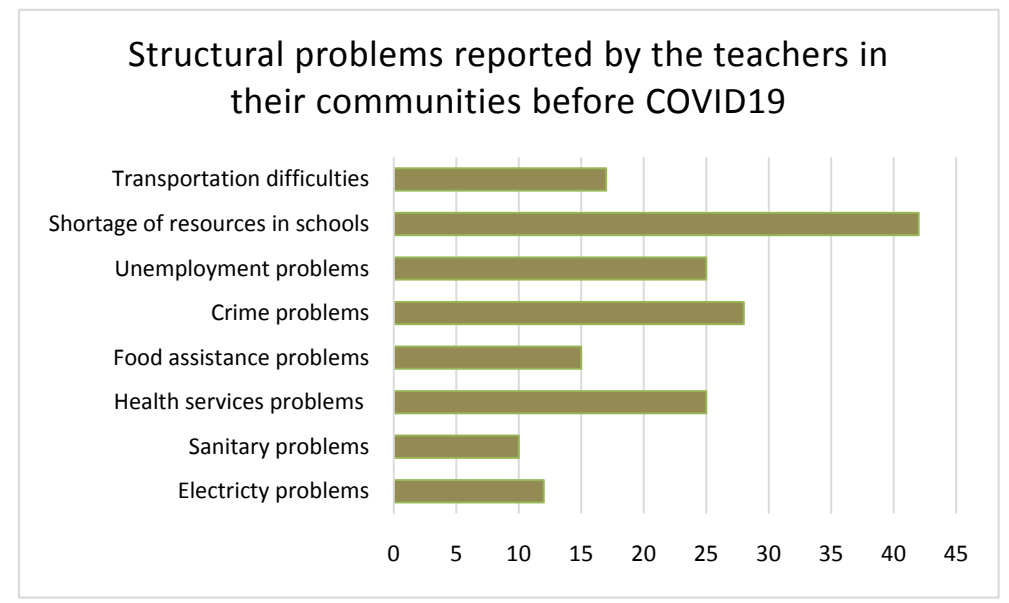

Figure 1. Structural problems reported by the teachers in their communities before the pandemic situation. Source: Own compilation.

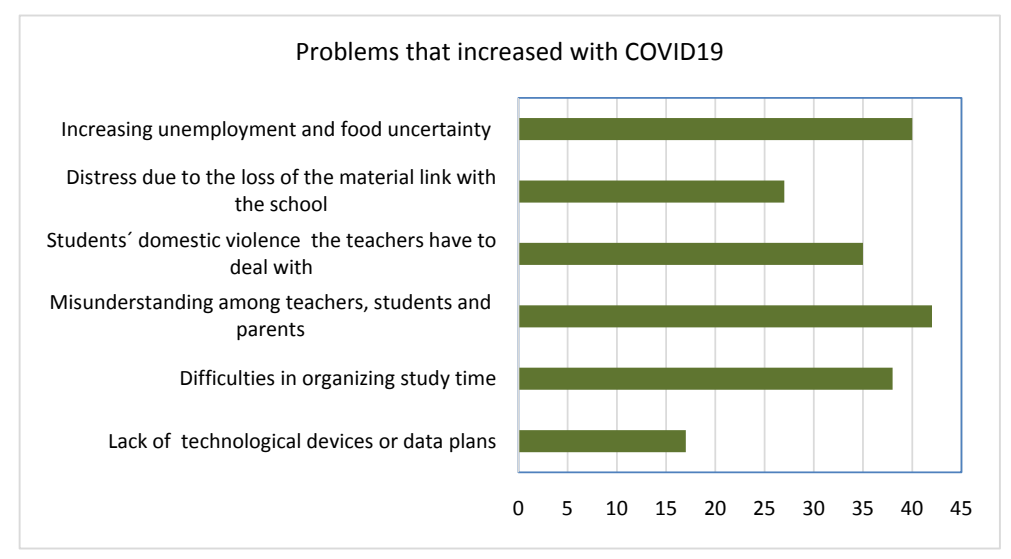

Figure 2. Problems that were increased by the pandemic situation. Source: Own compilation.

The data obtained with the last question of the interview, what do you think your professional activities will be like after the pandemic?, showed that from their teachers' viewpoint, the future scenarios will not be encouraging for them and their students if the current Colombian State does not invest a significant amount of money in educational resources. In sum, the answers to this question turned into claims and complaints towards the Colombian government for better education conditions and resources in long-neglected rural and urban regions of the country.

\section{Conclusion}

The objectives of the present research were, first, to identify the main transversal training areas demanded by the public policies to frame teacher training in undergraduate programs in Colombia and, second, to determine whether the work contexts in which in-service teachers of Básica Primaria and Básica Secundaria in different regions of the country favor or hamper the application of the main transversal competences demanded by the public policies in Education. The find- 
ings in relation to the first objective evidenced that there are two main training areas: science and technology and pedagogical research training. A general conclusion that can be drawn in regards to this finding is that all the teachers in the country, no matter whether they work in rural or urban regions, must have the opportunities to put into practice and hence enrich, in their work contexts, the competences they were equipped with in science and technology and pedagogical research training. It, in turns, suggests that all the teachers in Colombia should not have limitations in their work contexts to carry out research on pedagogy and resort to science and technological resources to both undertake investigations and disseminate and release information about the findings of their scientific research. The second objective of this study focuses on finding evidence whether the participants in this investigation are really exposed to conditions and resources in their workplaces to develop such competences.

The findings in relation to the second objective of this study evidenced that in-service teachers of Básica Primaria and Básica Secundaria, who work in different regions of the country, lack of time, technology and financial resources to put into practice, in their workplaces, the competences they were equipped with in pedagogical research training and science and technology. The participants expressed that although they have the skills, knowledge and foundations in science and technology and pedagogical research training, teachers hardly have the time to sit down to systematize their academic practices, because most of their time is spent on supporting their students in a wide range of difficulties that are not linked to teaching and learning processes. In fact, some of these teachers and students do not even have electricity or sanitary services.

Furthermore, the interviewed teachers said that their intellectual development is impoverished as they become solvers of families' economic problems, caregivers of children and other related roles. Consequently, they feel overwhelmed because "they are sellers of false hopes" since they recognized that with the training offered to their students, these pupils will hardly be able to enter university and become professionals. In this regard, it is important to point out that the Colombian Education system for Educación Básica Secundaria promotes as its main objective that students finish their Baccalaureate and obtain good results in higher education admission exams. This is obviously not possible for the vast majority of students in long-neglected rural trained under the deficiencies previously stated.

Based on the above, a final conclusion that can be drawn is that there is a gap between the higher education policies issued in Colombia and what some teachers can do in the Básica Primaria and Básica Secundaria contexts, with the competences developed in science and technology and pedagogical research training. This disparity seems to stem from government indifference towards the real needs teachers and students face in such contexts.

\section{Acknowledgements}

We would like to acknowledge the generous support of CLACSO and the Un- 
iversidad Distrital Francisco José de Caldas for providing us the evidences that bear the ideas provided in this paper.

\section{Conflicts of Interest}

We declare that there is no potential conflict of interest because the research was not sponsored by any private or public institution.

\section{References}

Bustamante, G. (2016). Acerca de los “derechos básicos de aprendizaje”. In Sobre los aprendizajes fundamentales (pp. 83-19). Bogotá: Red Colombiana para la Transformación Docente en Lenguaje.

Decreto 0272 (1998). Por el cual se establecen los requisitos de creación y funcionamiento de los programas académicos de pregrado y postgrado en Educación ofrecidos por las universidades y por las instituciones universitarias. Ministerio de Educación Nacional de Colombia.

Decreto 1075 (2015). Por medio del cual se expide el Decreto Único Reglamentario del Sector Educación. Ministerio de Educación Nacional de Colombia.

Decreto 1280 (2018). Por el cual se reglamenta el sistema de aseguramiento de la calidad de la educación superior, el registro calificado de que trata la ley 1188 de 2008 y los artículos 53 y 54 de la ley 30 de 1992 sobre acreditación. Ministerio de Educación Nacional de Colombia.

Decreto 1330 (2019). Por el cual se sustituye el capítulo 2 y se suprime el capítulo 7 del título 3 de la parte 5 del libro 2 del decreto 1075 de 2015-único reglamentario del sector educación. Ministerio de Educación Nacional de Colombia.

Decreto 2450 (2015). Por el cual se reglamentan las condiciones de calidad para el otorgamiento y renovación del registro calificado de los programas académicos de licenciatura y los enfocados a la educación, y se adiciona el Decreto 1075 de 2015, Único Reglamentario del Sector Educación. Ministerio de Educación Nacional de Colombia.

Decreto 4716 (2010). Por el cual se amplía la vigencia de registro calificado de programas en educación. Ministerio de Educación Nacional de Colombia.

Decreto 892 (2017). Por el cual se crea un régimen transitorio para la acreditación en alta calidad de los programas académicos de licenciaturas a nivel de pregrado. Ministerio de Educación Nacional de Colombia.

Dimate, C. (2017). Desarrollo profesional docente: Aporte a la construcción de políticas docentes. In Hacia la construcción de una política pública en formación de maestros (pp. 141-165). Bogotá: Editorial de la PUJ.

Ghioldi, R. (2006). El fantasma de la desigualdad educativa. Buenos Aires: Círculo de Legisladores de la Nación Argentina.

Giroux, H. (1990). Los profesores como intelectuales. Barcelona: Paidós.

Hernández-Sampieri, S., \& Mendoza, C. (2018). Metodología de la investigación: Las rutas cuantitativa, cualitativa y mixta. México: McGraw Hill.

Kumaravadivelu, B. (2012). Language Teacher Education for a Global Society: A Modular Model for Knowing, Analyzing, Recognizing, Doing and Seeing. New York: Routledge. https://doi.org/10.4324/9780203832530

Ley 1188 (2008). Por la cual se regula el registro calificado de programas de educación superior y se dictan otras disposiciones. 
Ley General de Educación (1994). Editorial Magisterio. Bogotá.

Ministerio de Educación Nacional de Colombia. (2013). Sistema colombiano de formación de educadores y lineamientos de políticas, SCFELP.

Montoya, M. (2017). Economía política y desarrollo: Su impacto en la construcción de la política pública en la formación de maestros. In Hacia la construcción de una política pública en formación de maestros (pp. 99-120). Bogotá: Editorial de la PUJ.

Ñaupas, H., Novoa, E., Mejía, E., \& Villagómez, A. (2013). Metodologáa de la investigación. Bogotá: Ediciones de la U.

Pandemnesis: Archivos Testimoniales, Diarios de la Experiencia, Crónicas y Fuentes desde América Latina (2020). CLACSO y Universidad Distrital Francisco José de Caldas. Bogotá.

Resolución 02041 (2016). Por la cual se establecen las características específicas de calidad de los programas de Licenciatura para la obtención, renovación o modificación del registro calificado. Ministerio de Educación Nacional de Colombia.

Rojas, M. (2015). Tipos de Investigación científica: Una simplificación de la complicada incoherente nomenclatura y clasificación. REDVET. Revista Electrónica de Veterinaria, 16, 1-14.

Serna-Dimas, A. (2004). Del pedagogo y el político: El saber de la escuela en la vida pública. Bogotá: Universidad Distrital Francisco José de Caldas. 